\title{
Erratum to: Synthesis of polyamine-grafted chitosan and its adsorption behavior
}

\author{
He-ping $\mathrm{Li}^{1} \cdot \mathrm{Hui} \mathrm{Li} i^{1} \cdot \mathrm{Yi} \mathrm{Liu}^{1}$
}

Published online: 10 March 2016

(C) Iran Polymer and Petrochemical Institute 2016

\section{Erratum to: Iran Polym J (2016) 25:277-284 \\ DOI 10.1007/s13726-016-0420-1}

In the original publication of the article the affiliation is incomplete. The complete affiliation is:

School of Chemistry and Biological Engineering, Changsha University of Science and Technology, Changsha 410114, China.

The online version of the original article can be found under doi:10.1007/s13726-016-0420-1.

He-ping Li

lihp@csust.edu.cn

1 School of Chemistry and Biological Engineering, Changsha

University of Science and Technology, 410114 Changsha,

China 